\title{
Key roles of hydrophobic rings of TM2 in gating of the $\alpha 9 \alpha 10$ nicotinic cholinergic receptor
}

\author{
${ }^{1}$ Paola V. Plazas, ${ }^{2}$ María J. De Rosa, ${ }^{1}$ María E. Gomez-Casati, ${ }^{1,4}$ Miguel Verbitsky, \\ ${ }^{1,5}$ Noelia Weisstaub, ${ }^{1,3}$ Eleonora Katz, ${ }^{2}$ Cecilia Bouzat \& ${ }^{* 1}$ Ana Belén Elgoyhen
}

\begin{abstract}
${ }^{1}$ Instituto de Investigaciones en Ingeniería Genética y Biología Molecular (INGEBI), CONICET-UBA, Vuelta de Obligado 2490, Buenos Aires 1428, Argentina; ${ }^{2}$ Instituto de Investigaciones Bioquímicas de Bahía Blanca, UNS-CONICET, Bahía Blanca F-8000FWB, Argentina and ${ }^{3}$ Departamento de Fisiología, Biología Molecular y Celular, Facultad de Ciencias Exactas y Naturales, Universidad de Buenos Aires, Buenos Aires 1428, Argentina
\end{abstract}

1 We have performed a systematic mutagenesis of three hydrophobic rings $\left(17^{\prime}, 13^{\prime}\right.$ and $\left.9^{\prime}\right)$ within transmembrane region (TM) 2 of the $\alpha 9 \alpha 10$ nicotinic cholinergic receptor (nAChR) to a hydrophilic (threonine) residue and compared the properties of mutant receptors reconstituted in Xenopus laevis oocytes.

2 Phenotypic changes in $\alpha 9 \alpha 10$ mutant receptors were evidenced by a decrease in the desensitization rate, an increase in both the $\mathrm{EC}_{50}$ for $\mathrm{ACh}$ as well as the efficacy of partial agonists and the reduction of the allosteric modulation by extracellular $\mathrm{Ca}^{2+}$.

3 Mutated receptors exhibited spontaneous openings and, at the single-channel level, an increased apparent mean open time with no major changes in channel conductance, thus suggesting an increase in gating of the channel as the underlying mechanism.

4 Overall, the degrees of the phenotypes of mutant receptors were more overt in the case of the centrally located $\mathrm{V} 13^{\prime} \mathrm{T}$ mutant.

5 Based on the atomic model of the pore of the electric organ of the Torpedo ray, we can propose that the interactions of side chains at positions $13^{\prime}$ and $9^{\prime}$ are key ones in creating an energetic barrier to ion permeation.

6 In spite of the fact that the roles of the TM2 residues are mostly conserved in the distant $\alpha 9 \alpha 10$ member of the nAChR family, their mechanistic contributions to channel gating show significant differences when compared to other nAChRs. These differences might be originated from slight differential intramolecular rearrangements during gating for the different receptors and might lead each nAChR to be in tune with their physiological roles.

British Journal of Pharmacology (2005) 145, 963-974. doi:10.1038/sj.bjp.0706224; published online 16 May 2005

Keywords: Nicotinic receptors; channel gating; Cys-loop receptors; ionotropic receptors; acetylcholine

Abbreviations: ACh, acetylcholine; BAPTA-AM, 1,2-bis(2-aminophenoxy)ethane- $N, N, N^{\prime}, N^{\prime}$-tetraacetic acid-acetoxymethyl ester; nAChR, nicotinic acetylcholine receptor; TM, transmembrane domain

\section{Introduction}

Nicotinic acetylcholine receptors (nAChRs) are members of the 'Cys-loop' family of neurotransmitter-gated ion channels, which also includes $\mathrm{GABA}_{\mathrm{A}}, \mathrm{GABA}_{\mathrm{C}}$, glycine, 5- $\mathrm{HT}_{3}$ and some invertebrate anionic glutamate receptors (LeNovere \& Changeux, 1995). They are complexes of protein subunits which co-assemble to form an ion channel gated through the binding of the neurotransmitter. The transmembrane domain 2 (TM2) lines the channel pore and is involved in determining ion selectivity. Residues that participate in channel gating as well as the location of the gate within TM2 has been the subject of numerous studies for several members of the family. In the case of the muscle nAChR, the use of the substituted cysteine accessibility method has suggested that the gate is

*Author for correspondence: E-mail: elgoyhen@dna.uba.ar ${ }^{4}$ Current address: Columbia Genome Center, Columbia University, 1150 St Nicholas Ave., New York, NY 10032, U.S.A.

${ }^{5}$ Current address: Columbia University, 1051 Riverside Drive, New York, NY 10032, U.S.A. located on the cytoplasmic end of TM2 (Akabas et al., 1994; Wilson \& Karlin, 1998). Using this method, a more centrally located gate within TM2 has been identified for the $5-\mathrm{HT}_{3}$ receptor (Panicker et al., 2002). Moreover, a peptide backbone mutagenesis study has suggested that the central to extracellular residues, $13^{\prime}, 16^{\prime}$ and $19^{\prime}$, are involved in channel gating (England et al., 1999).

Mutagenesis studies of a conserved leucine (L9') have implicated the middle of TM2 in gating of the nAChRs, $\mathrm{GABA}_{\mathrm{A}}$ and $\mathrm{GABA}_{\mathrm{C}}$ receptors (Revah et al., 1991; Filatov \& White, 1995; Labarca et al., 1995; Chang \& Weiss, 1998, 1999). A similar approach has been performed to show the participation of $13^{\prime}$ valine (V) within TM2 of the $\alpha 7 \mathrm{nAChR}$ (Galzi et al., 1992; Corringer et al., 1999). On the other hand, the use of rate equilibrium linear free energy has suggested that the TM2 $\alpha$ helix of muscle nAChRs bends or swivels about its central residues during gating, with the conformational change of the extracellular half preceding the movement of the intracellular half upon opening (Cymes et al., 2002). Finally, 
a $4 \AA$ atomic model of the closed pore of the nAChR of the electric organ of the Torpedo ray has indicated that the gate is a constricting hydrophobic girdle that includes $\mathrm{L}^{\prime}$ and $\mathrm{V}^{\prime} 3^{\prime}$ at the middle of the membrane (Miyazawa et al., 2003).

Within the nAChR family, the $\alpha 9$ and $\alpha 10$ subunits are the latest that have been cloned (Elgoyhen et al., 1994; 2001). They are distant members of the $\mathrm{nAChR}$ family and form a distinct phylogenetic subfamily (Elgoyhen et al., 1994; 2001; LeNovere et al., 2002). Moreover, heteromeric receptors assembled from these subunits exhibit a peculiar mixed nicotinic-muscarinic pharmacological profile which is distinct from that of other nAChRs and shares properties with $\mathrm{GABA}_{\mathrm{A}}$, glycine and $5-\mathrm{HT}_{3}$ receptors. A hallmark of this receptor is that it is not activated by nicotine, the prototypic agonist of the family. Given its lower conservation and distinct properties when compared with other members of the nAChR family, experimental evidence is necessary to probe if residues that have been shown to exert key roles in channel gating are functionally conserved in the $\alpha 9 \alpha 10$ receptor.

We have now performed a mutagenesis study of the TM2 region of the $\alpha 9 \alpha 10 \mathrm{nAChR}$, including three hydrophobic rings of amino acids (outer $17^{\prime}$, valine $13^{\prime}$ and equatorial $9^{\prime}$ ) proposed to face the lumen of the channel in the stratified organization of an $\alpha$-helical ionic pore (Bertrand et al., 1993; Karlin \& Akabas, 1995; Miyazawa et al., 2003). Hydrophobic residues were mutated to the hydrophilic residue threonine. We have compared the phenotypes of receptors assembled from mutated $\alpha 9$ and $\alpha 10$ subunits at each position. We present evidence indicating that, as reported for other nAChRs, the centrally located amino acids at $9^{\prime}$ and $13^{\prime}$ are involved in gating of the $\alpha 9 \alpha 10 \mathrm{nAChR}$. However, different from that reported for muscle nAChRs (Filatov \& White, 1995; Labarca et al., 1995), the $9^{\prime} \mathrm{T}$ mutation is not independent, equivalent or multiplicative in its effect on the responses to acetylcholine (ACh) probably indicating subunit asymmetry in the role these leucines play in activation. Moreover, it is the $13^{\prime} \mathrm{T}$ and not the $9^{\prime} \mathrm{T}$ mutation, as observed for the $\alpha 7 \mathrm{nAChRs}$, that renders a more drastic phenotype. Based on the proposed atomic model for the gate of nAChRs (Miyazawa et al., 2003), this result could suggest that hydrophobic interactions at $13^{\prime}$ might contribute the most to create an energetic barrier to ion permeation. Further mutations to residues other than threonine would be needed in order to prove this notion.

\section{Methods}

\section{Generation of mutant receptors}

Site-directed mutagenesis of the $\alpha 9$ and $\alpha 10$ rat cDNAs, subcloned in a modified pGEMHE vector (Elgoyhen et al., 1994; 2001), was performed with the QuickChange SiteDirected Mutagenesis kit (Stratagene, La Jolla, CA, U.S.A.). Mutations were confirmed by sequence analysis to verify that only the desired nucleotide changes were present.

\section{Expression of recombinant receptors in Xenopus laevis oocytes}

Capped cRNAs were in vitro transcribed from linearized plasmid DNA templates using the mMessage mMachine T7
Transcription Kit (Ambion Corporation, Austin, TX, U.S.A.). The maintenance of $X$. laevis, as well as the preparation and cRNA injection of stage V and VI oocytes, has been described in detail elsewhere (Katz et al., 2000). Typically, oocytes were injected with $50 \mathrm{nl}$ of RNase-free water containing 0.01-1.0 ng of cRNAs (at a 1:1 molar ratio) and maintained in Barth's solution at $17^{\circ} \mathrm{C}$.

Electrophysiological recordings were performed 2-6 days after cRNA injection under two-electrode voltage clamp with a Geneclamp 500 amplifier (Axon Instruments Corp., Union City, CA, U.S.A.). Both voltage and current electrodes were filled with $3 \mathrm{M} \mathrm{KCl}$ and had resistances of $\sim 1-2 \mathrm{M} \Omega$. Data acquisition was performed using a Digidata 1200 and the pClamp 7.0 software (Axon Instruments Corp., Union City, CA, U.S.A.). Data were analyzed using Clamp Fit from the pClamp 6.1 software. During electrophysiological recordings, oocytes were continuously superfused $\left(\sim 10 \mathrm{ml} \mathrm{min}^{-1}\right)$ with normal frog saline comprised of (mM): $115 \mathrm{NaCl}, 2.5 \mathrm{KCl}, 1.8$ $\mathrm{CaCl}_{2}$ and 10 HEPES buffer, $\mathrm{pH}$ 7.2. When the effect of nominally zero $\mathrm{Ca}^{2+}$ was assessed (Figure 2), experiments were carried out in oocytes injected with $7.5 \mathrm{ng}$ of an oligonucleotide (5'-GCTTTAGTAATTCCCATCCTGCCAT GTTTC-3') antisense to connexinC38 mRNA (Arellano et al., 1995; Ebihara, 1996), in order to minimize the activation of the oocyte's nonselective inward current through a hemigap junction channel in response to the reduction of the external divalent cation concentration. However, in the case of the V13 ' $\mathrm{T}$ mutant, current due to both the activation of the nonselective hemigap junction channel plus the constitutively active mutant channels rendered leak currents that were too big to compensate. Therefore, the concentration-response curves of Figure 2c were performed (both those with and without $\mathrm{Ca}^{2+}$ ) in a saline solution that contained $0.5 \mathrm{mM}$ $\mathrm{Mg}^{2+}$, in order to minimize the activation of the nonselective inward current. As reported previously, $\mathrm{Mg}^{2+}$ does not potentiate ACh currents through $\alpha 9 \alpha 10$ receptors; however, it does produce a channel block (Weisstaub et al., 2002). Drugs were applied in the perfusion solution of the oocyte chamber. To minimize activation of the endogenous $\mathrm{Ca}^{2+}$-sensitive chloride current (Elgoyhen et al., 2001), all experiments were performed in oocytes incubated with the $\mathrm{Ca}^{2+}$ chelator 1,2bis(2-aminophenoxy)ethane- $N, N, N^{\prime}, N^{\prime}$-tetraacetic acid-acetoxymethyl ester (BAPTA-AM, $100 \mu \mathrm{M}$ ) for 3-4h prior to electrophysiological recordings.

Concentration-response curves were normalized to the maximal agonist response in each oocyte. The mean and standard error of the mean of peak current responses are represented. Agonist concentration-response curves were iteratively fitted with the equation: $I / I_{\max }=A^{n} /\left(A^{n}+\mathrm{EC}_{50}^{n}\right)$, where $I$ is the peak inward current evoked by the agonist at concentration $A ; I_{\max }$ is current evoked by the concentration of agonist eliciting a maximal response; $\mathrm{EC}_{50}$ is the concentration of agonist inducing half-maximal current response and $n$ is the Hill co-efficient.

\section{Current-voltage (I-V) relationships}

$I-V$ relationships were obtained by applying $2 \mathrm{~s}$ voltage ramps from -120 to $+50 \mathrm{mV}, 10 \mathrm{~s}$ after the peak response to $\mathrm{ACh}$ from a holding potential $\left(V_{\text {hold }}\right)$ of $-70 \mathrm{mV}$. Leakage correction was performed by digital subtraction of the $I-V$ curve obtained by the same voltage ramp protocol prior to the 
application of ACh. Generation of voltage protocols and data acquisition were performed using a Digidata 1200 and the pClamp 6.1 or 7.0 software (Axon Instruments Corp., Union City, CA, U.S.A.). Data were analyzed using Clamp fit from the pClamp 6.1 software.

\section{Single-channel recordings}

Single-channel currents were recorded in the cell-attached and outside-out patch configuration (Hamill \& Sakmann, 1981) at $20^{\circ} \mathrm{C}$. Before the experiments, the oocytes were incubated for $4 \mathrm{~h}$ in a buffer containing BAPTA-AM in order to block endogenous calcium-activated chloride channels. The vitelline membrane was removed with fine forceps from the oocytes just before the experiments. The bath and pipette solution contained $150 \mathrm{mM} \mathrm{NaCl}, 0.5 \mathrm{mM} \mathrm{CaCl}_{2}, 5.6 \mathrm{mM} \mathrm{KCl}$ and $10 \mathrm{mM}$ HEPES (pH 7.4). Solutions free of magnesium and with low calcium were used in order to minimize the channel block (Weisstaub et al., 2002). Patch pipettes were pulled from Kimax capillary tubes (Kimble, Vineland, NJ, U.S.A.) and coated with Sylgard (Dow Corning, Midland, MI, U.S.A.). Pipette resistance ranged from 5 to $7 \mathrm{M} \Omega$. ACh was added to the pipette solution.

The resting potential of the oocytes in this bath solution varied from -30 to $-50 \mathrm{mV}$. Currents were recorded using an Axopatch 200 B patch-clamp amplifier (Axon Instruments Corp., Union City, CA, U.S.A.), digitized at $5 \mu$ s intervals with the PCI-61 1E interface (National Instruments, Austin, TX, U.S.A.), recorded to the hard disk of a computer using the program Acquire (Bruxton Corporation, Seattle, WA, U.S.A.), and detected by the half-amplitude threshold criterion using the program TAC 4.0.10 (Bruxton Corporation, Seattle, WA, U.S.A.) at a final bandwidth of $8 \mathrm{kHz}$ (Bouzat et al., 1994; 2002). Open-time histograms were plotted using a logarithmic abscissa and a square root ordinate and fitted to the sum of exponentials by maximum likelihood using the program TACFit (Bruxton Corporation, Seattle, WA, U.S.A.).

Statistical significance was evaluated by the Student's $t$-test (two-tailed, unpaired samples). Multiple comparisons were performed with a one-way ANOVA followed by Tukey's test. $P<0.05$ was considered significant.

\section{Materials}

ACh chloride and choline chloride were bought from Sigma Chemical Co. (St Louis, MO, U.S.A.). ICS 205,930 $\mathrm{HCl}$, (-)-nicotine-di- $d$-tartrate and $(+)$-muscarine chloride were obtained from RBI (Natik, MA, U.S.A.). Drugs were dissolved in distilled water as $10 \mathrm{mM}$ stocks and stored aliquoted at $-20^{\circ} \mathrm{C}$. BAPTA-AM (Molecular Probes, Eugene, OR, U.S.A.) was stored at $-20^{\circ} \mathrm{C}$ as aliquots of a $100 \mathrm{~mm}$ solution in dimethyl sulfoxide, thawed and diluted 1000 -fold into saline solution shortly before incubation of the oocytes.

All experimental protocols were carried out in accordance with the National Institute of Health Guide for the Care and Use of Laboratory Animals (NIH Publications No. 80-23) revised 1978.

\section{Results}

Mutant receptors exhibit a decreased desensitization rate and an increased $A C h C_{50}$

Figure 1a shows an alignment of the TM2 region of different nAChRs and the positions of amino acids (one-letter code) that have been mutated. The numbering used is the one that has been adopted to allow comparison of homologous amino acids from different types of neurotransmitter-gated channels. Position $1^{\prime}$ corresponds to the start of the TM2 region. The residues that have been mutated to threonine are the three hydrophobic rings (outer $17^{\prime}, 13^{\prime}$ and equatorial $9^{\prime}$ ) of amino acids proposed to face the lumen of the channel in the stratified organization of an $\alpha$-helical ionic pore (Bertrand et al., 1993; Karlin \& Akabas, 1995; Miyazawa et al., 2003). Residues were mutated to threonine, since the introduction of this amino acid has rendered drastic phenotypes in other ligand-gated ion channels (Bertrand et al., 1992; Labarca et al., 1995; Chang \& Weiss, 1998).

We first examined whole-cell responses of Xenopus oocytes expressing wild-type and mutant receptors. All mutants yielded functional receptors that responded to $\mathrm{ACh}$ (Figure 1b). Peak responses to ACh of double mutants $\left(\alpha 9^{*} \alpha 10^{*}\right)$ were similar to those obtained in the wild-type receptor, except in the case of the $\mathrm{L}^{\prime} \mathrm{T}$, where a reduction was observed (Table 1). Representative responses to increasing concentrations of $\mathrm{ACh}$ are shown in Figure $1 \mathrm{~b}$ and their respective concentration-response curves in Figure 1c. $\mathrm{EC}_{50}$ and Hill coefficient values from a fit of the Hill equation to these data are provided in Table 1. The table also includes data derived from concentration-response curves performed in receptors assembled from single-mutant subunits, that is either $\alpha 9$ or $\alpha 10$ were mutated at each position and co-injected with the wild-type partner subunit. In the case of the double mutants, mutations increased the sensitivity for $\mathrm{ACh}$, with no change in Hill coefficients, as evidenced by a reduction in the $\mathrm{EC}_{50}$. The rank order of potency of ACh for mutated receptors was: $13^{\prime} \mathrm{T}>9^{\prime} \mathrm{T}>17^{\prime} \mathrm{T}(P<0.05)$. Thus, the major shift in the $\mathrm{EC}_{50}$ for $\mathrm{ACh}, 86$-fold, was observed for the $13^{\prime} \mathrm{T}$ mutant. In spite of the fact that a sole detectable population of receptors is found in oocytes with a $(\alpha 9) 2(\alpha 10) 3$ stoichiometry (Plazas and Elgoyhen, unpublished observations), no differences in $\mathrm{EC}_{50}$ values were observed at positions $13^{\prime}$ and $9^{\prime}$ when comparing the $\alpha 9 * \alpha 10$ to the $\alpha 9 \alpha 10 *$ mutant receptors, suggesting that at these positions both types of subunits contribute in an asymmetric and nonadditive manner to a pentameric assembly. On the other hand, differences in $\mathrm{EC}_{50}$ values were observed at position $17^{\prime}$ (Table 1), where a bigger shift in the $\mathrm{EC}_{50}$ was observed when mutating the $\alpha 10$ subunit. It should be noted that at the concentrations of ACh used in the present study (maximus of $30 \mu \mathrm{M}$ for wild-type receptors) we did not find evidence for channel block produced by $\mathrm{ACh}$, as assessed by a rebound in currents after washing. All following experiments were performed with the double-mutant receptors.

Mutant receptors exhibited a decrease in the rate of desensitization at prolonged applications of $100 \mu \mathrm{M} \mathrm{ACh}$ (Figure 1d), that can be quantified by the percent of maximal peak current remaining after a $30 \mathrm{~s}$ application of $\mathrm{ACh}$ (Table 1). Moreover, while wild-type currents quickly decayed after removal of the agonist, a substantial residual current could be recorded for several seconds in the case of $\mathrm{V} 13^{\prime} \mathrm{T}$ 
a

TM2

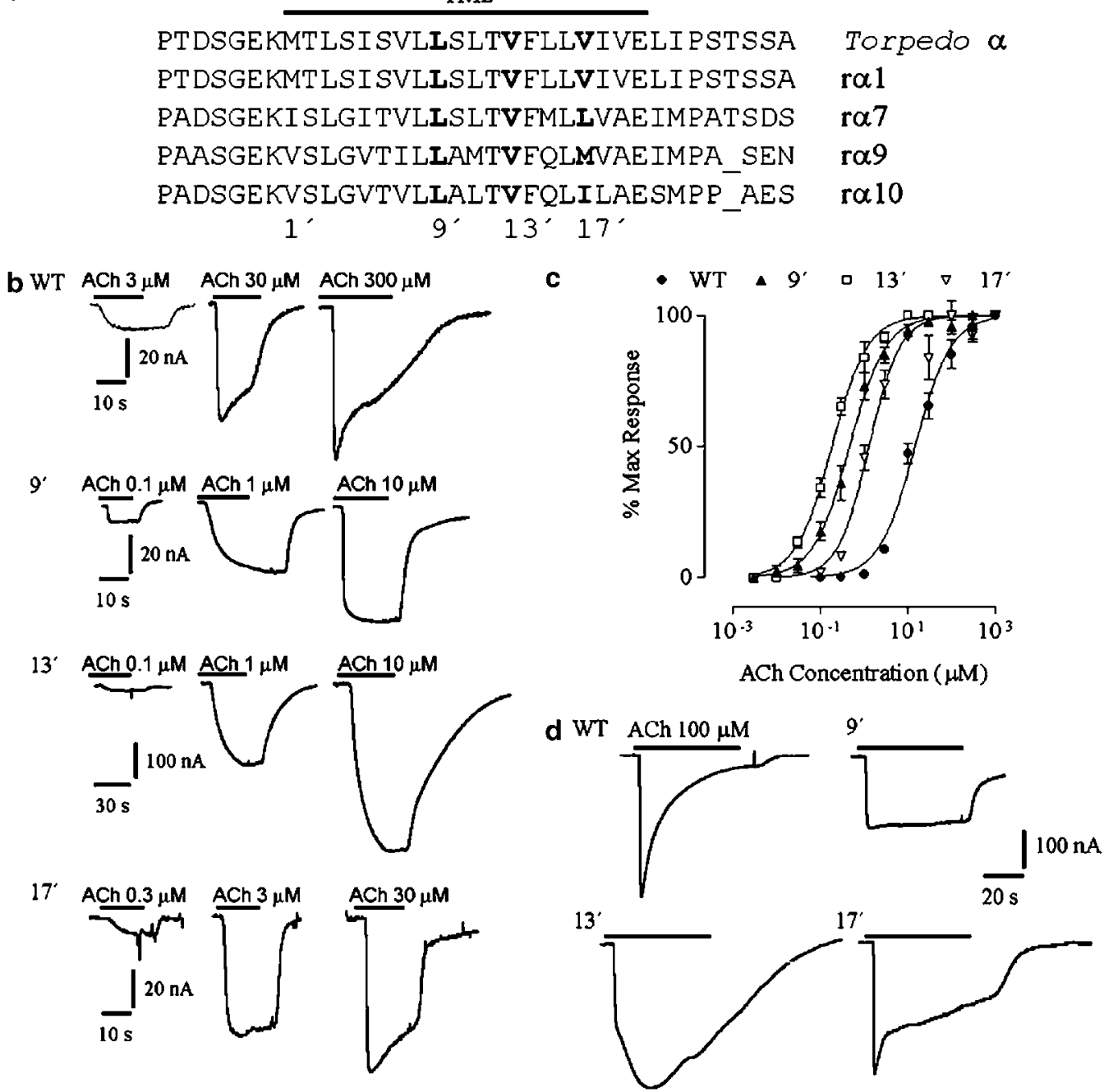

Figure 1 Responses of mutant receptors to ACh. (a) Alignment of the amino-acid sequences of the Torpedo $\alpha$, rat $\alpha 1, \alpha 7, \alpha 9$ and $\alpha 10 \mathrm{nAChR}$ subunits. Residues that have been mutated are shown in bold. (b) Representative responses to increasing concentrations of ACh for wild-type and each mutant receptor. (c) Concentration-response curves to ACh. Peak current values were normalized and referred to the maximal peak response to $\mathrm{ACh}$ in each case. The mean and s.e.m. of four to five experiments per group are shown. (d) Representative responses of wild-type and mutant receptors to a 1-min application of $100 \mu \mathrm{M} \mathrm{ACh}$.

(Figure 1d). In addition, activation of macroscopic currents in $\mathrm{V} 13^{\prime} \mathrm{T}$ had a fast and a slow component.

\section{Allosteric modulation by extracellular $\mathrm{Ca}^{2+}$ is reduced in mutant receptors}

It has been shown that external $\mathrm{Ca}^{2+}$ modulates the activity of several nAChRs. In particular, the $\alpha 9 \alpha 10$ receptor is highly permeable to $\mathrm{Ca}^{2+}$, and it is both potentiated and blocked by physiological concentrations of external $\mathrm{Ca}^{2+}$ (Weisstaub et al., 2002). Potentiation is voltage-independent and results in a decrease in the $\mathrm{EC}_{50}$ of the receptor for $\mathrm{ACh}$, thus suggesting that $\mathrm{Ca}^{2+}$ interacts at an extracellular binding site to allosterically modulate coupling between ligand binding and gating. On the other hand, blockage is voltage dependent, suggesting that the site of action of this ion lies within the channel pore and might result from the permeation process.

The bar diagram of Figure 2a shows the responses to a fixed concentration of $\mathrm{ACh}$ at varying concentrations of extracellular $\mathrm{Ca}^{2+}$ for wild-type, $9^{\prime} \mathrm{T}$ and $13^{\prime} \mathrm{T}$ mutant receptors at a holding potential of $-90 \mathrm{mV}$. The concentration of ACh used in each case was near the corresponding $\mathrm{EC}_{50}$ value derived from the concentration-response curves of Figure 1:10 $\mu \mathrm{M}$ for the wild type, $0.5 \mu \mathrm{M}$ for the $9^{\prime} \mathrm{T}$ and $0.1 \mu \mathrm{M}$ for the $13^{\prime} \mathrm{T}$ mutant. Responses were normalized to the value obtained at $1.8 \mathrm{mM} \mathrm{Ca}^{2+}$ for each case. As previously shown for the $\alpha 9 \alpha 10$ wild-type receptor (Weisstaub et al., 2002), responses to ACh were potentiated by $\mathrm{Ca}^{2+}$ up to $0.5 \mathrm{mM}$, and blocked by higher concentrations of this ion. Moreover, in oocytes that had a low level of subunit expression, responses in the absence of $\mathrm{Ca}^{2+}$ were often too small to be detected. On the other hand, in the case of the $9^{\prime} \mathrm{T}$ and $13^{\prime} \mathrm{T}$ mutants, the potentiating effect of $\mathrm{Ca}^{2+}$ was not observed. Responses were highest at low $\mathrm{Ca}^{2+}$ concentrations, suggesting that channel gating by ACh became independent of the presence of extracellular $\mathrm{Ca}^{2+}$. Blockage by $\mathrm{Ca}^{2+}$ was still observed. However, the magnitude of block by $\mathrm{Ca}^{2+}$ of the $13^{\prime} \mathrm{T}$ mutant was reduced when compared to that of the $9^{\prime} \mathrm{T}$ mutant (percentage of response at $3 \mathrm{mM} \mathrm{Ca}^{2+}$ compared to $0.1 \mathrm{~mm} \mathrm{Ca}{ }^{2+}: 9^{\prime} \mathrm{T}, 29 \pm 2 \%$ and $13^{\prime} \mathrm{T}, 51 \pm 2 \%$, $n=4-10, P<0.001)$ 
Table 1 Properties of mutant receptors

\begin{tabular}{lcccc}
\hline & Peak current $(\mathrm{nA})$ & $\mathrm{I}_{30 s} / \mathrm{I}_{\max }(\%)$ & $E C_{50}(\mu \mathrm{M})$ & $\mathrm{n}_{\text {Hill }}$ \\
WT & $600 \pm 100(40)$ & $16 \pm 3(11)$ & $14.6 \pm 5.3(5)^{\mathrm{a}}$ & $1.1 \pm 0.1$ \\
& & & & \\
$L 9^{\prime} T$ & & & & \\
$\alpha 9^{*} \alpha 10$ & $547 \pm 145(30)$ & $89 \pm 2(12)^{\mathrm{b}}$ & $5.30 \pm 0.32(8)$ & $1.7 \pm 0.1$ \\
$\alpha 9 \alpha 10^{*}$ & $155 \pm 35(12)^{\mathrm{c}}$ & $88 \pm 5(6)^{\mathrm{b}}$ & $5.62 \pm 0.40(8)$ & $1.8 \pm 0.2$ \\
$\alpha 9^{*} \alpha 10^{*}$ & $235 \pm 40(22)^{\mathrm{c}}$ & $92 \pm 2(12)^{\mathrm{b}}$ & $0.46 \pm 0.04(5)^{\mathrm{a}}$ & $1.1 \pm 0.1$ \\
& & & & \\
$V 13^{\prime} T$ & & & & \\
$\alpha 9^{*} \alpha 10$ & $632 \pm 269(5)$ & $80 \pm 6(8)^{\mathrm{b}}$ & $0.42 \pm 0.02(5)$ & $1.1 \pm 0.1$ \\
$\alpha 9 \alpha 10^{*}$ & $237 \pm 77(10)$ & $91 \pm 2(8)^{\mathrm{b}}$ & $0.46 \pm 0.02(5)$ & $1.4 \pm 0.1$ \\
$\alpha 9^{*} \alpha 10^{*}$ & $531 \pm 116(16)$ & $74 \pm 4(23)^{\mathrm{b}}$ & $0.17 \pm 0.01(5)^{\mathrm{a}}$ & $1.1 \pm 0.1$ \\
& & & & \\
$M / I 17^{\prime} T$ & & & & \\
$\alpha 9^{*} \alpha 10$ & $101 \pm 12(15)^{\mathrm{d}}$ & $80 \pm 1(18)^{\mathrm{b}}$ & $5.47 \pm 0.71(5)$ & $1.2 \pm 0.2$ \\
$\alpha 9 \alpha 10^{*}$ & $660 \pm 281(15)$ & $73 \pm 3(9)^{\mathrm{b}}$ & $2.86 \pm 0.60(9)$ & $1.1 \pm 0.2$ \\
$\alpha 9^{*} \alpha 10^{*}$ & $430 \pm 67(10)$ & $67 \pm 3(11)^{\mathrm{b}}$ & $1.09 \pm 0.13(4)^{\mathrm{a}}$ & $1.5 \pm 0.2$
\end{tabular}

All parameters were determined as described in Methods.

${ }^{a} \mathrm{wt}>17^{\prime}>9^{\prime}>13^{\prime}, P<0.05$, one-way ANOVA followed by Tukey's test.

${ }^{\mathrm{b}} P<0.01$ with respect to wild type.

${ }^{\mathrm{c}} P<0.05$.

${ }^{\mathrm{d}} P<0.01$ with respect to wild type, Student's $t$-test.

Figure $2 \mathrm{~b}$ shows representative $I-V$ curves for $9^{\prime} \mathrm{T}$ and $13^{\prime} \mathrm{T}$ mutant receptors, obtained by applying 2-s voltage ramps $(-120$ to $+50 \mathrm{mV}), 10 \mathrm{~s}$ after the peak response to ACh at different $\mathrm{Ca}^{2+}$ concentrations. The apparent reversal potentials at $1.8 \mathrm{mM} \mathrm{Ca}^{2+},-11 \pm 1, n=22$, for wild-type receptors (Elgoyhen et al., 2001), $-16 \pm 4, n=6$, for the $9^{\prime}$ and $-9 \pm 3$, $n=6$, for the $13^{\prime}$ mutants were not significantly different. Near the reversal potential, the $9^{\prime} \mathrm{T}$ mutant showed a marked rectification, similar to that previously reported for the wildtype receptor (Elgoyhen et al., 2001; Weisstaub et al., 2002). In contrast, almost linear $I-V$ curves were observed in the case of the $13^{\prime} \mathrm{T}$ mutant. Different from what had been previously described for the $\alpha 9 \alpha 10$ wild-type receptor (Weisstaub et al., 2002), in the case of mutant receptors, responses were smaller the higher the $\mathrm{Ca}^{2+}$ concentration, at all concentrations of the ion tested (Figure 2b). This result is consistent with that shown in Figure 2a, and indicates that whereas the allosteric potentiation by $\mathrm{Ca}^{2+}$ is lost in the mutants, its blocking effect is still maintained. Calcium block was clearly voltagedependent in the case of the $9^{\prime} \mathrm{T}$ receptor, where no blocking effect was observed at potentials positive to $0 \mathrm{mV}$. On the other hand, while block by $\mathrm{Ca}^{2+}$ was still voltage-dependent in the case of the $13^{\prime} \mathrm{T}$ mutant, the dependency upon membrane potential diminished. This is evidenced when comparing the ratio of current at $3 \mathrm{mM}$ to $0.2 \mathrm{mM} \mathrm{Ca}^{2+}$ at -110 and $+40 \mathrm{mV}$, respectively: $9^{\prime} \mathrm{T}, 0.31 \pm 0.08$ and $0.98 \pm 0.05(n=6)$; $13^{\prime} \mathrm{T}, 0.27 \pm 0.09$ and $0.59 \pm 0.10(n=6)$.

The bar diagram of Figure $2 \mathrm{a}$ shows the effect of $\mathrm{Ca}^{2+}$ at only one concentration of $\mathrm{ACh}$. In order to analyze if the potentiating effect of $\mathrm{Ca}^{2+}$ is lost at all concentrations of the agonist, full concentration-response curves to ACh were performed and compared at nominally zero and $1.8 \mathrm{mM}$ $\mathrm{Ca}^{2+}$ (Figure 2c). In all cases, responses were normalized to the maximal response at $\mathrm{Ca}^{2+} 1.8 \mathrm{mM}$. In the case of the wildtype receptor, responses to all concentrations of $\mathrm{ACh}$ tested were potentiated in the presence of $\mathrm{Ca}^{2+}$. The maximal response achieved in nominally zero $\mathrm{Ca}^{2+}$ was $31 \pm 2 \%$ of that at $1.8 \mathrm{mM}$, and a decrease in potency without changes in the
Hill coefficient was observed (nominally zero $\mathrm{Ca}^{2+}: \mathrm{EC}_{50}$, $83.1 \pm 9.2 \mu \mathrm{M} ; \quad n_{\text {Hill }}, 1.2 \pm 0.3, \quad n=5 ; 1.8 \mathrm{mM} \mathrm{Ca}^{2+}: \quad \mathrm{EC}_{50}$, $\left.22.6 \pm 2.4 \mu \mathrm{M} ; n_{\mathrm{Hill}}, 1.1 \pm 0.2, n=5\right)$. In the case of the $9^{\prime} \mathrm{T}$ mutant, responses were potentiated by $\mathrm{Ca}^{2+}$ at concentrations of ACh below $1 \mu \mathrm{M}$ and blocked at higher concentrations of the agonist. Potentiation was significant at $0.3 \mu \mathrm{M} \mathrm{ACh}$, where responses at zero $\mathrm{Ca}^{2+}$ were $1.3 \pm 0.4 \%, n=5$, and at $1.8 \mathrm{mM}$ $\mathrm{Ca}^{2+} 38.7 \pm 12.3 \%, n=5$, of the maximum obtained at $1.8 \mathrm{mM}$ $\mathrm{Ca}^{2+}$. On the contrary, responses of the $13^{\prime} \mathrm{T}$ mutant to ACh were not potentiated by $\mathrm{Ca}^{2+}$ and the blocking effect of this ion was evidenced at low and high concentrations of $\mathrm{ACh}$. Note that in a previous work we have shown that responses in zero $\mathrm{Ca}^{2+}$ achieve the maximal response at high concentrations of ACh (Weisstaub et al., 2002). However, those experiments were performed in a solution devoid of divalent cations, whereas the present experiments were carried out in the presence of $\mathrm{Mg}^{2+}$, for reasons explained in experimental procedures. Moreover, parameters derived from Figure 3c are not comparable to those of Table 1 because of the different ionic composition of the saline solution.

Mutant receptors retained the high $\mathrm{Ca}^{2+}$ permeability previously described for the $\alpha 9 \alpha 10$ wild-type receptor (Weis-

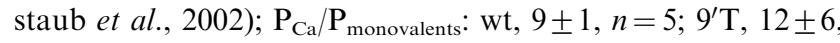
$n=5 ; 13^{\prime} \mathrm{T}, \quad 11 \pm 5, \quad n=7 ; 17^{\prime} \mathrm{T}, \quad 12 \pm 6, \quad n=7$, data not illustrated).

\section{Choline, a partial agonist of wild-type receptors is a full agonist of mutant receptors}

Choline, the metabolite of the enzymatic degradation of ACh, has been shown to activate several nAChRs, including $\alpha 7$ and $\alpha 9$ (Papke et al., 1996; Verbitsky et al., 2000). Figure 3 indicates the concentration-response curves to choline, for both wild-type $\alpha 9 \alpha 10$ and V13'T mutant receptors. Responses were normalized to the maximal responses to ACh in each case. Curves for other mutations are not shown, but rendered similar results. Choline was a partial agonist of wild-type receptors, with a maximal response that reached $36 \%$ of the maximum to $\mathrm{ACh}$ and an $\mathrm{EC}_{50}$ of $538 \mu \mathrm{M}$ (Table 2). On the other hand, in the case of the mutant receptors, choline behaved as a full agonist, reaching maximal responses similar to those of ACh. As reported in Figure 1 and Table 1 for ACh, mutations increased the sensitivity for choline, as evidenced by a reduction in the $\mathrm{EC}_{50}$. The rank order of potency of choline for mutated receptors was: $13^{\prime} \mathrm{T}>9^{\prime} \mathrm{T}>17^{\prime} \mathrm{T}(P<0.05)$. Thus, the major shift in the $\mathrm{EC}_{50}$ for choline, 49 -fold, was observed for the $\mathrm{V} 13^{\prime} \mathrm{T}$ mutant.

\section{Classical antagonists of wild-type receptors are agonists of mutant receptors}

The wild-type $\alpha 9 \alpha 10 \mathrm{nAChR}$ is blocked by the classical nicotinic receptor agonist, nicotine, as well as by the classical muscarinic receptor agonist, muscarine. Moreover, ICS 205, 930, a classical $5-\mathrm{HT}_{3}$ receptor antagonist, is one of the most potent blockers of $\alpha 9 \alpha 10 \mathrm{nAChRs}$ (Elgoyhen et al., 2001). This pharmacological profile is a hallmark of the peculiar $\alpha 9 \alpha 10$ nAChR. As shown in Figure 4, these antagonists of wild-type receptors behaved as agonists of mutant $13^{\prime} \mathrm{T}$ and $9^{\prime} \mathrm{T}$ receptors. For all the three compounds, a higher efficacy was obtained in the case of the $\mathrm{V} 13^{\prime} \mathrm{T}$ mutant receptor when compared to the L9'T (Table 2 and Figure 4). Moreover, while 


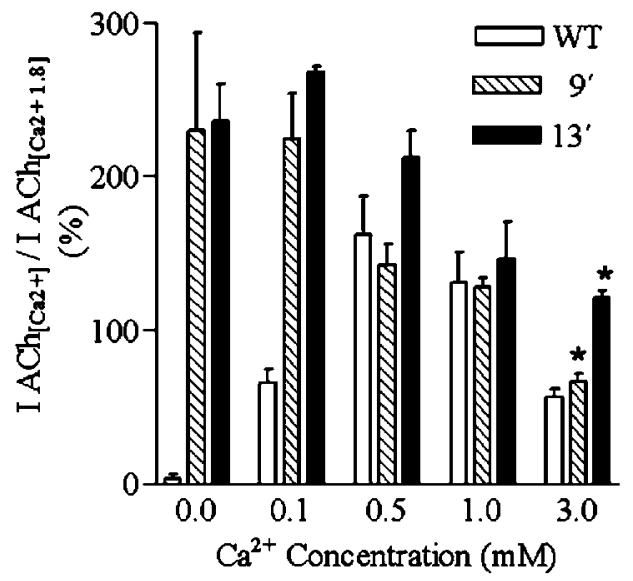

C

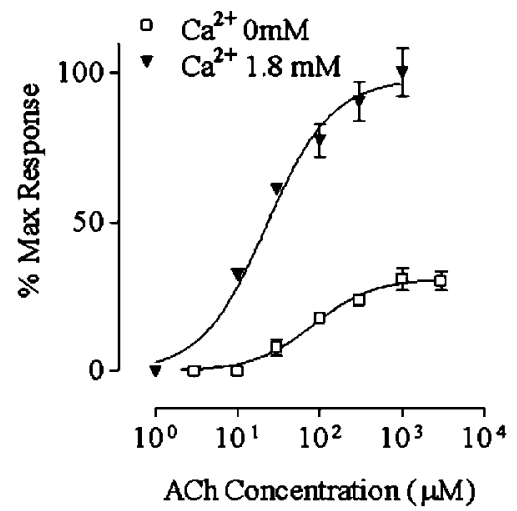

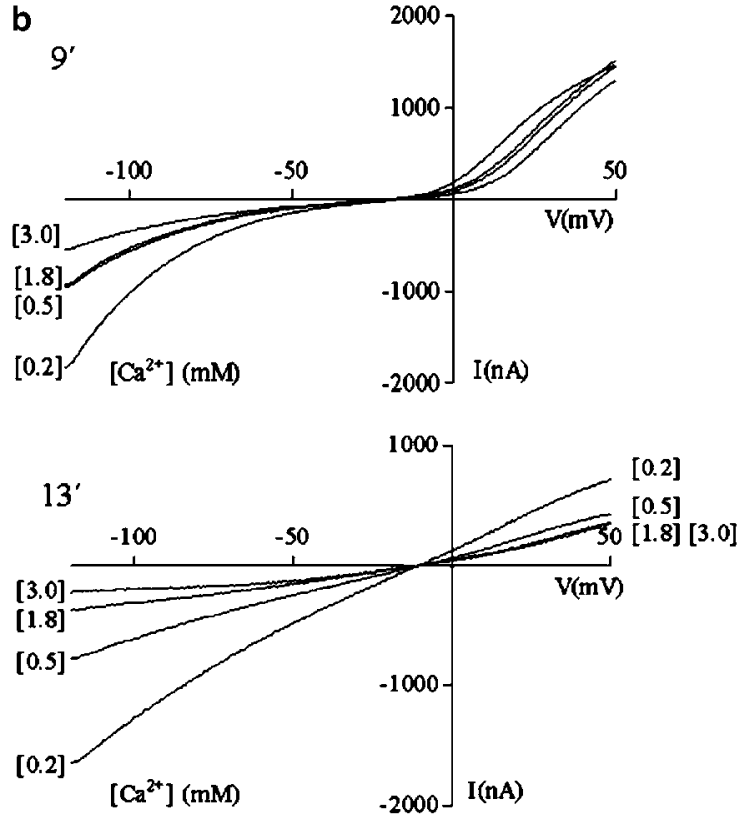

$9^{*}$

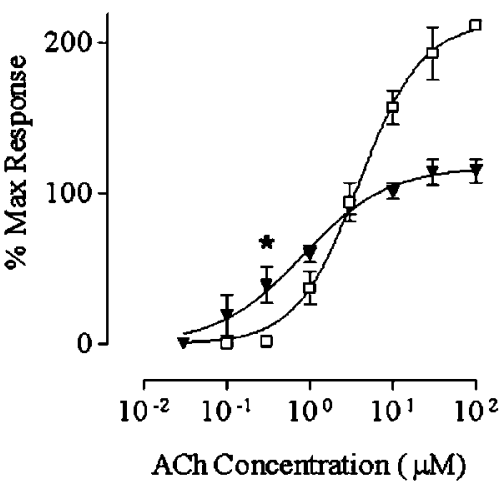

13'

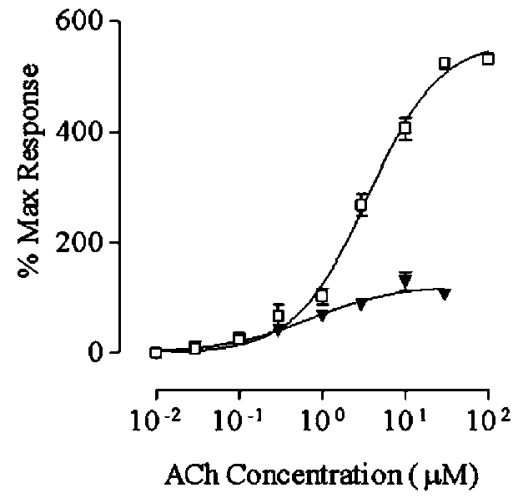

Figure 2 Modulation of ACh responses by extracellular calcium. (a) Bar diagram illustrating the effects of extracellular $\mathrm{Ca}^{2+}$ on responses to ACh in wild-type and mutant receptors at a membrane holding potential of $-90 \mathrm{mV}$. The concentration of ACh used in each case was near the corresponding $\mathrm{EC}_{50}$ value derived from the concentration-response curves of Figure 1: $10 \mu \mathrm{M}$ for the wt, $0.5 \mu \mathrm{M}$ for the $9^{\prime}$ and $0.1 \mu \mathrm{M}$ for the $13^{\prime}$ mutant. Current amplitudes obtained at different $\mathrm{Ca}^{2+}$ concentrations in each oocyte were normalized with respect to that obtained at $1.8 \mathrm{mM}$ in the same oocyte. Each bar represents the mean and s.e.m. of the normalized response obtained in different oocytes $\left(n=4-10\right.$ per bar). ${ }^{*} P<0.05$ with respect to the corresponding value at $0.1 \mathrm{mM} \mathrm{Ca}^{2+}$. (b) Representative $I-V$ curves, obtained by application of a voltage ramp protocol $(-120$ to $+50 \mathrm{mV}, 2 \mathrm{~s}) 10 \mathrm{~s}$ after the peak response to either $0.5 \mu \mathrm{M} \mathrm{ACh}$ for the $9^{\prime}$ (upper panel, $n=6$ ) or $0.1 \mu \mathrm{M} \mathrm{ACh}$ for the $13^{\prime}$ mutant (lower panel, $n=6$ ). Oocytes were voltageclamped at $-70 \mathrm{mV}$, and ramps were performed at different $\mathrm{Ca}^{2+}$ concentrations. (c) Concentration-response curves to ACh, performed either at nominally zero or $1.8 \mathrm{mM} \mathrm{Ca}^{2+}$. Responses were normalized to the maximum obtained at $1.8 \mathrm{mM} \mathrm{Ca}^{2+}$ for each case. The mean and s.e.m. of four to 10 experiments per group are shown. ${ }^{*} P<0.05$ with respect to the corresponding value at nominally zero $\mathrm{Ca}^{2+}$.

ICS 205,930 became a full agonist of $\mathrm{V} 13^{\prime} \mathrm{T}$ with an $\mathrm{EC}_{50}$ of $8 \mathrm{nM}$, it behaved as a partial agonist of $\mathrm{L}^{\prime} \mathrm{T}$, achieving $50 \%$ of the maximal response to $\mathrm{ACh}$ with an $\mathrm{EC}_{50}$ of $40 \mathrm{~nm}$. ICS 205,930, nicotine as well as muscarine also became agonists of receptors mutated at the $17^{\prime}$ position. However, maximal responses were too small $(4 \%, n=8$, of the maximal response to $\mathrm{ACh}$ in the case of nicotine) and therefore full concentration-response curves could not be performed.

\section{Mutant receptors exhibit spontaneous openings}

Mutations to threonine at positions $13^{\prime}$ and $9^{\prime}$ of the $\alpha 7 \mathrm{nAChR}$ induce spontaneous openings of the receptor (Bertrand et al.,
1997; Corringer et al., 1999). This is evidenced by a decrease in the leak current in the presence of the competitive antagonist methyllycaconitine. In the case of the $\alpha 9 \alpha 10 \mathrm{nAChR}$, classical antagonists that did not behave as agonists of mutant receptors as those described in Figure 4 did cause a deflection of the baseline current in the positive direction, that is, a reduction of the leak current (Figure 5). This was the case for compounds such as strychnine, D-tubocurarine, atropine, bicuculline and serotonin. No modification of the holding current was observed in noninjected oocytes or in oocytes injected with wild-type receptors. This result can be interpreted as a closure of receptors that are spontaneously opened in the absence of agonist (Bertrand et al., 1997; Corringer et al., 1999). 
Figure 5a shows representative traces of responses of mutant $9^{\prime} \mathrm{T}$ and $13^{\prime} \mathrm{T}$ receptors to strychnine, including a maximal response to $\mathrm{ACh}$ in each case for comparison. The maximal response to strychnine reached $87 \%(n=9), 20 \%(n=12)$ and $0.6 \%(n=5)$ of the maximal current evoked by ACh in the $13^{\prime} \mathrm{T}, 9^{\prime} \mathrm{T}$ and $17^{\prime} \mathrm{T}$ mutants, respectively. Thus, a more pronounced phenotype was observed when mutating $\mathrm{V} 13^{\prime}$ to threonine. This was correlated with the fact that receptors injected with the $13^{\prime} \mathrm{T}$ mutant subunits exhibited unusually large holding currents when the membrane potential was voltage clamped at $-70 \mathrm{mV}$ (wt: $77 \pm 5 \mathrm{nA}, \quad n=55 ; 9^{\prime}$ : $65 \pm 6 \mathrm{nA}, \quad n=55 ; 13^{\prime}: 600 \pm 57 \mathrm{nA}, n=55,17^{\prime}: 60 \pm 2 \mathrm{nA}$, $n=40)$.

The midpoint of the concentration-response curve, $\mathrm{EC}_{50}$, is an empirical parameter that depends on the rate constants for ligand binding and unbinding, as well as those for channel opening and closing, that is, channel gating (Colquhoun, 1998). Thus, changes in the $\mathrm{EC}_{50}$ for $\mathrm{ACh}$ could derive from changes in the channel gating properties. This seems to be the case for the mutations in the TM2 region of the $\alpha 9 \alpha 10 \mathrm{nAChR}$, since the $\mathrm{ACh} \mathrm{EC}_{50}$ values for mutant receptors were inversely correlated to the degree of spontaneous openings (gating) of the channels (Figure 5b).
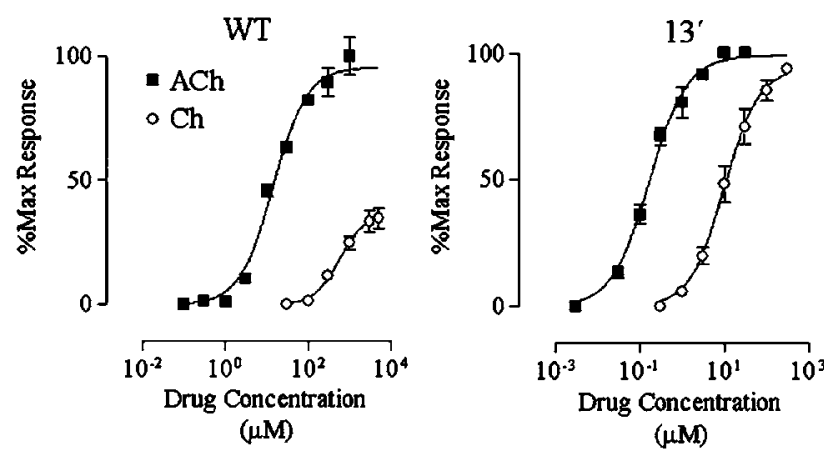

Figure 3 Choline is a full agonist of mutant receptors. Concentration-response curves to choline were performed. Peak current values were normalized and referred to the maximal peak response to $\mathrm{ACh}$ in each case. The mean and s.e.m. of four and seven experiments for wild-type and $\mathrm{V} 13^{\prime} \mathrm{T}$ receptors, respectively, are shown. The $\mathrm{EC}_{50}$ and Hill coefficients are shown in Table 2.
Single-channel recordings reveal an increased apparent mean open time of mutant receptors

In order to characterize at the single-channel level the properties of the $\alpha 9 \alpha 10$ wild-type and mutant receptors, we performed single-channel recordings in the cell-attached patch configuration in oocytes injected with wild-type, L9'T and $\mathrm{V} 13^{\prime} \mathrm{T} \alpha 9$ and $\alpha 10$ subunits.

To first determine the basal channel activity of the oocytes, we recorded channels from noninjected oocytes. Channel openings were detected in more than $90 \%$ of the patches (Figure 6a). Channel activity was similar to that corresponding to stretch-activated channels previously described (Taglietti \& Toselli, 1988). At a pipette potential of $+120 \mathrm{mV}$, at which the membrane potential is about $-150 \mathrm{mV}$, the amplitude histogram showed a main component of $7.1 \pm 1.2 \mathrm{pA}(n=3)$. At positive potentials $(70$ to $120 \mathrm{mV})$, the $I / V$ curve was linear. The conductance, calculated by the slope of the curve, was $76 \mathrm{pS}$. The open-time histogram could be well fitted with one component of $730 \pm 170 \mu \mathrm{s}(n=3)$.

After characterizing the basal activity, we recorded singlechannel currents under the same conditions, from oocytes injected with $\alpha 9$ and $\alpha 10$ wild-type and mutant subunits. The
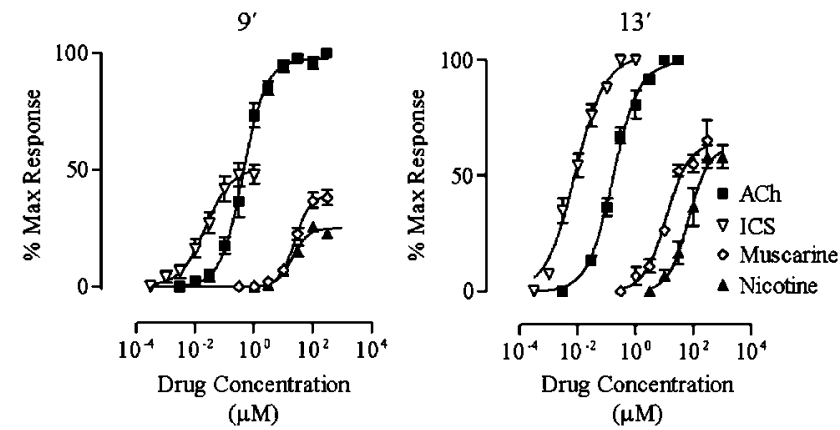

Figure 4 Effect of classical antagonists of the $\alpha 9 \alpha 10 \mathrm{nAChR}$ Concentration-response curves to ACh, ICS 205,930, muscarine and nicotine were performed. Peak current values were normalized and referred to the maximal peak response to $\mathrm{ACh}$ in each case. The mean and s.e.m. are shown. The number of experiments for each set of data is shown in Table 2. The $\mathrm{EC}_{50}$, Hill coefficients and maximal responses are shown in Table 2.

Table 2 Responses of mutant receptors to different agonists

\begin{tabular}{|c|c|c|c|c|}
\hline & $W T$ & $L 9^{\prime} T$ & $V 13^{\prime} T$ & $M / I 17^{\prime} T$ \\
\hline $\mathrm{Ch}$ & $\begin{array}{l}\mathrm{EC}_{50}=538 \pm 140 \mu \mathrm{M} \\
\text { Max Resp }=36 \pm 3 \% \\
n=4\end{array}$ & $\begin{array}{l}\mathrm{EC}_{50}=20 \pm 2 \mu \mathrm{M} \\
\text { Max Resp }=97 \pm 3 \% \\
n=5\end{array}$ & $\begin{array}{l}\mathrm{EC}_{50}=10 \pm 1 \mu \mathrm{M} \\
\text { Max Resp }=98 \pm 2 \% \\
n=7\end{array}$ & $\begin{array}{l}\mathrm{EC}_{50}=27 \pm 3 \mu \mathrm{M} \\
\text { Max Resp }=94 \pm 2 \% \\
n=4\end{array}$ \\
\hline ICS & $\begin{array}{l}\mathrm{IC}_{50}=0.04 \pm 0.01 \mu \mathrm{M} \\
n=4\end{array}$ & $\begin{array}{l}\mathrm{EC}_{50}=0.04 \pm 0.01 \mu \mathrm{M} \\
\operatorname{Max} \operatorname{Resp}=49 \pm 4 \% \\
n=8\end{array}$ & $\begin{array}{l}\mathrm{EC}_{50}=8.2 \pm 0.6 \mathrm{nM} \\
\operatorname{Max} \operatorname{Resp}=98 \pm 3 \% \\
n=7\end{array}$ & \\
\hline $\mathrm{Nic}$ & $\begin{array}{l}\mathrm{IC}_{50}=4.6 \pm 1.0 \mu \mathrm{M} \\
n=4\end{array}$ & $\begin{array}{l}\mathrm{EC}_{50}=20 \pm 4 \mu \mathrm{M} \\
\text { Max Resp }=25 \pm 2 \% \\
n=6\end{array}$ & $\begin{array}{l}\mathrm{EC}_{50}=70 \pm 14 \mu \mathrm{M} \\
\text { Max Resp }=63 \pm 7 \% \\
n=4\end{array}$ & \\
\hline Musc & $\begin{array}{l}\mathrm{IC}_{50}=40.9 \pm 5.1 \mu \mathrm{M} \\
n=5\end{array}$ & $\begin{array}{l}\mathrm{EC}_{50}=24 \pm 1 \mu \mathrm{M} \\
\text { MaxResp }=39 \pm 3 \% \\
n=7\end{array}$ & $\begin{array}{l}\mathrm{EC}_{50}=12 \pm 3 \mu \mathrm{M} \\
\text { Max Resp }=60 \pm 4 \% \\
n=7\end{array}$ & \\
\hline
\end{tabular}

All parameters were determined as described in Methods. $\mathrm{IC}_{50}$ values for the wild-type receptor are included for comparison and have been extracted from Elgoyhen et al. (2001). 


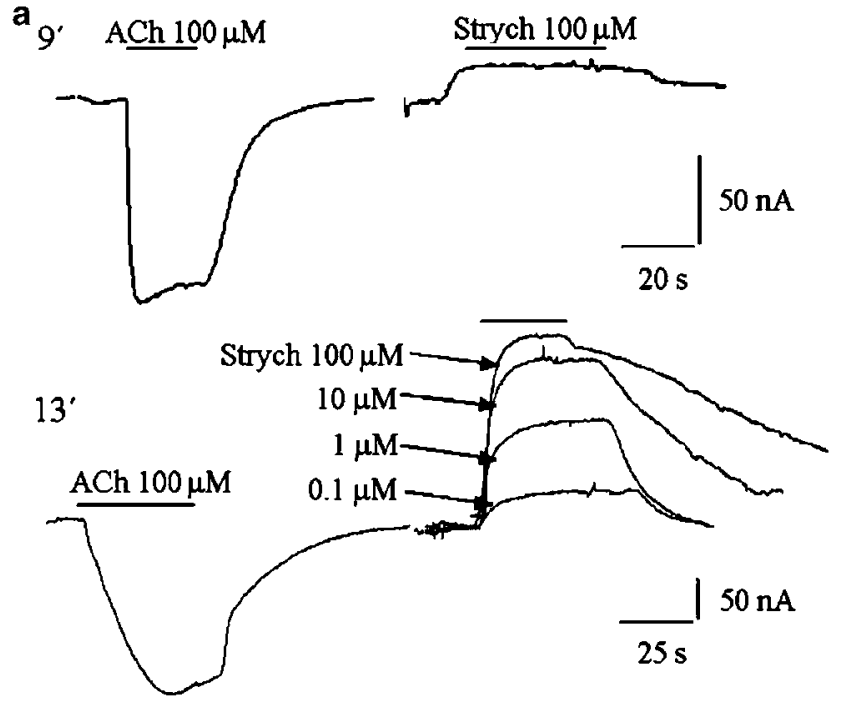

b

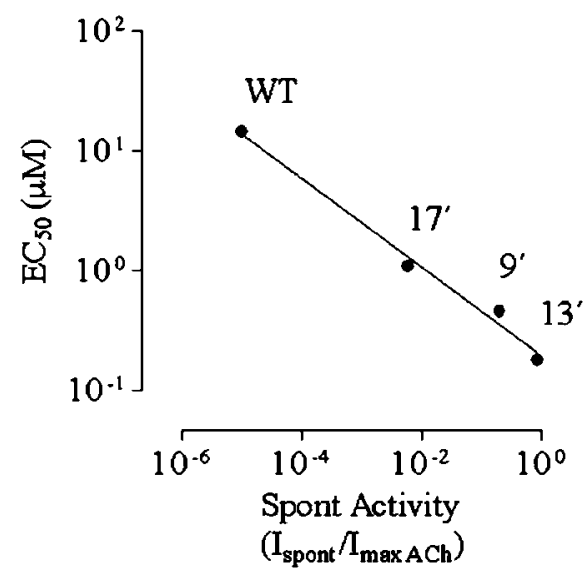

Figure 5 Block of leak current by strychnine. (a) Representative responses $(n=5$ per mutant) to strychnine of oocytes injected with either the $9^{\prime}$ (upper panel) or the $13^{\prime}$ (lower panel) mutant receptors. Note the deflection of currents in the upward direction in the presence of the drug. A maximal response to $\mathrm{ACh}$ in each oocyte is shown for comparison. (b) Correlation of the $\mathrm{EC}_{50}$ values for $\mathrm{ACh}$ for each receptor with the degree of spontaneous activity calculated as the percentage of the maximal response to strychnine compared to that of ACh $\left(r^{2}: 0.989\right)$

concentration of $\mathrm{ACh}$ used was near the one that produces a maximal response for each receptor, derived from macroscopic currents. Single-channel recordings from oocytes expressing wild-type $\alpha 9 \alpha 10 \mathrm{nAChRs}$ in the presence of $60 \mu \mathrm{M}$ ACh revealed a new population of channels that were neither observed in the absence of agonist nor in oocytes injected with the mutant subunits (Figure 6a). These channels were observed in only one of 76 seals. At a pipette potential of $+120 \mathrm{mV}$, the mean amplitude of these channels was $18.4 \mathrm{pA}$, and thus could be well distinguished from the stretch-activated channels. As shown in the histograms, a single class of conductance was observed for both wild-type and mutant channels. The opentime histogram showed two components, a main one of $90 \mu \mathrm{s}$ (relative area 0.77 ) and a longer one of $320 \mu$ s (relative area $0.24)$. The channel activity appeared in clusters of openings at $60 \mu \mathrm{M} \mathrm{ACh}$ (Figure 6a).
In three of 33 recordings from oocytes injected with $\alpha 9$ and $\alpha 10$ subunits both carrying the L9'T mutation, we observed single channels activated by $1 \mu \mathrm{M} \mathrm{ACh}$, with a mean amplitude of $13.8 \pm 2.1 \mathrm{pA}(n=3)$, similar to that determined in wild-type receptors (Figure 6a). The open-time histograms showed two components, which were both longer than those observed in wild-type receptors. Channel activity appeared in clusters. At $1 \mu \mathrm{M} \mathrm{ACh}$, the open components and relative areas were: $165 \pm 30 \mu \mathrm{s}(0.63 \pm 0.07)$ and $1.1 \pm 0.4 \mathrm{~ms}(0.37 \pm 0.07)$.

In three of 29 recordings performed in oocytes injected with $\alpha 9$ and $\alpha 10$ subunits both carrying the V13'T mutation, we observed single channels activated by $1 \mu \mathrm{M}$ ACh with a mean amplitude of $13.5 \pm 2 \mathrm{pA}(n=3)$, similar to that observed in wild-type $\alpha 9 \alpha 10$ receptors (Figure 6a). Channel activity was observed in very tight clusters. Clusters contained openings which were dramatically prolonged with respect to those of wild-type and $9^{\prime} \mathrm{T}$ mutants, as well as briefer closings. In two recordings, the open-time histograms were similar and were fitted with two components. The averages of the mean durations and relative areas for both recordings were $390 \pm 160 \mu \mathrm{s}(0.38 \pm 0.3)$, and $5.5 \pm 0.5 \mathrm{~ms}(0.63 \pm 0.3)$. In the third recording, in addition to the first two open components shown before, $205 \mu \mathrm{s}(0.4)$ and $3.7 \mathrm{~ms}(0.3)$, an additional significantly prolonged component was also observed $(57.7 \mathrm{~ms}$, relative area 0.3 ).

To further determine that the observed channels corresponded to $\alpha 9 \alpha 10 \mathrm{nAChRs}$, we performed recordings from outside-out patches before and after exposure to a 30 -s pulse of ACh. We were able to detect channels in only two patches. One patch was obtained from oocytes injected with wild-type and the other with $\mathrm{V} 13^{\prime} \mathrm{T}$ subunits. As shown in Figure $6 b$, the channels were indistinguishable from those recorded in the cell-attached patch configuration for each type of receptor (Figure 6a). Again, the V13'T channels were dramatically prolonged with respect to wild-type nAChRs. Each type of channel was not detected either before the application of $\mathrm{ACh}$ or in oocytes injected with other subunits. Thus, these results further support the fact that the channels observed in the cell-attached configuration correspond to $\alpha 9 \alpha 10$ nAChRs.

Although the heterologous expression of some channels leads to a differential concentration in the animal pole of the oocyte (Grigoriev et al., 1999), we did not find any difference in the number of positive seals when the patches were performed in either pole. Thus, assuming that receptors are homogeneously distributed in the oocyte surface, and considering an average single current of $10 \mathrm{pA}$, a macroscopic current of $600 \mathrm{nA}$ at $-70 \mathrm{mV}$, and a probability of opening of 0.5 , the number of receptors per $\mu \mathrm{M}^{2}$ would be as low as 0.04 . Owing to the low rate of success of finding channels other than the stretch-activated ones, we were not able to perform a thorough characterization of these channels in order to unequivocally determine their kinetic properties. However, the following lines of evidence allowed us to suggest that the shown channels should correspond to $\alpha 9 \alpha 10$ nAChRs: (i) the channels were never observed in noninjected oocytes; (ii) the kinetics of the channels were different for wild-type, L9' $\mathrm{T}$ and $\mathrm{V}^{\prime} 3^{\prime} \mathrm{T}$ mutants, and the changes were the ones expected from observations of the macroscopic currents; (iii) in two outside-out patches, channels were detected after application of ACh and showed the expected amplitudes and kinetics. 
a

Control

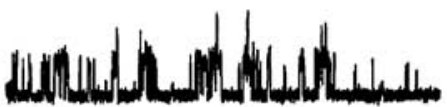

WT $60 \mu \mathrm{M} \mathrm{ACh}$
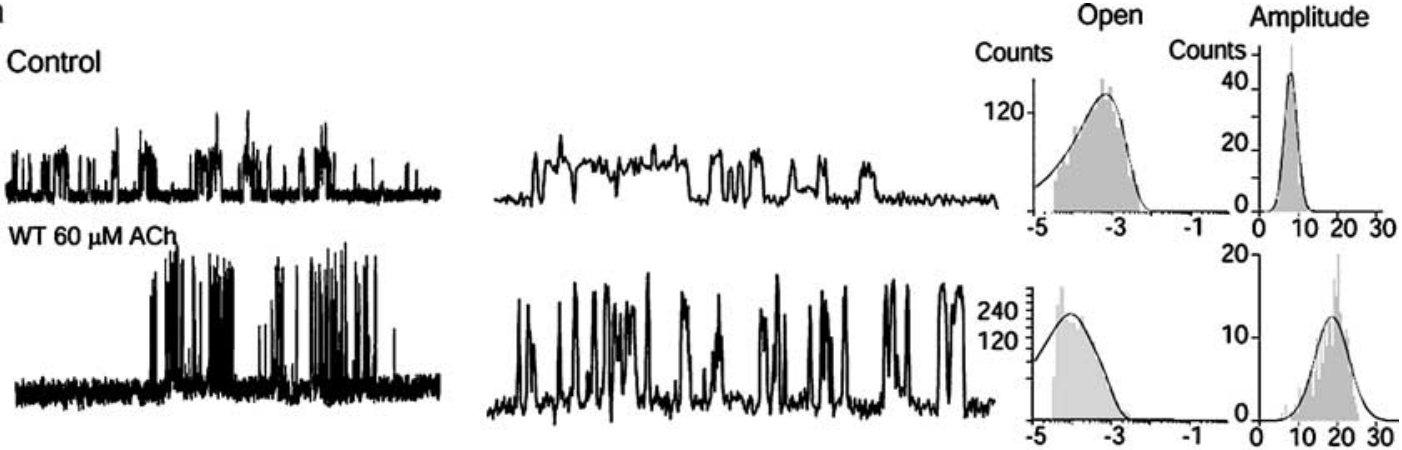

L9'T $1 \mu \mathrm{M} \mathrm{ACh}$
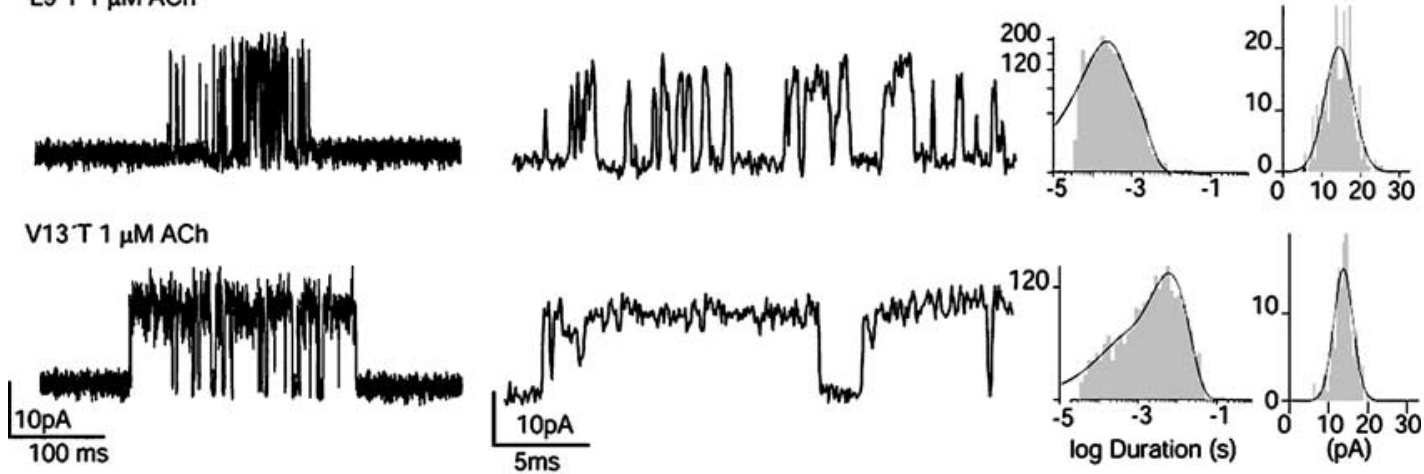

b

WT $100 \mu \mathrm{M} \mathrm{ACh}$

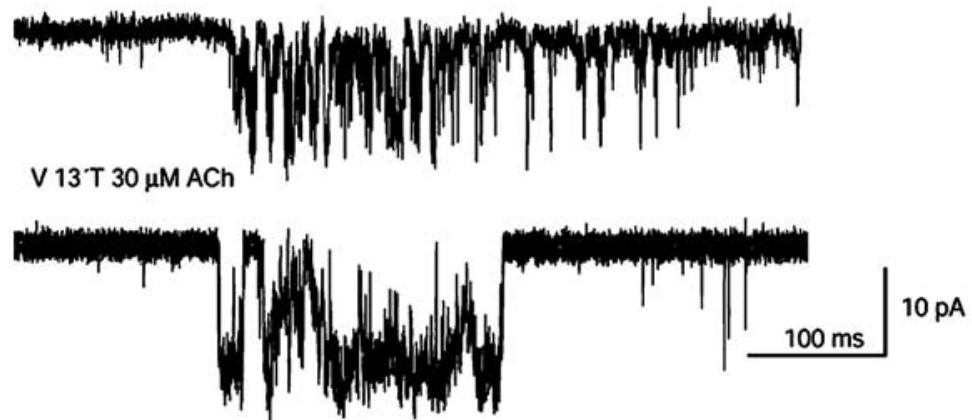

Figure 6 Single-channel recordings of wild-type and mutant $\alpha 9 \alpha 10$ nAChRs. (a) (left) Channel traces recorded in the cell-attached configuration from oocytes injected with wild-type, L9'T and V13'T subunits. As a control, endogenous channels were recorded from noninjected oocytes. Traces are shown at two different time scales for each recording. Currents are displayed at a bandwidth of $5 \mathrm{kHz}$ with channel openings as upward deflections. Pipette potential: $120 \mathrm{mV}$. To the right, open-time and amplitude histograms of the corresponding recordings are shown. (b) Channel traces obtained after application of ACh to outside-out patches from oocytes injected with wild-type or ${\mathrm{V} 13^{\prime} \mathrm{T}} \alpha \alpha 10$ subunits. Currents are displayed at a bandwidth of $5 \mathrm{kHz}$ with channel openings as downward deflections. Pipette potential: $-70 \mathrm{mV}$.

\section{Discussion}

\section{Centrally located residues are involved in channel gating}

The present results provide functional evidence suggesting that the centrally located positions $9^{\prime}$ and $13^{\prime}$ of TM2 are major contributors to channel gating, in the case of the $\alpha 9 \alpha 10$ nAChR. Based on the atomic model described for the electric organ of the Torpedo ray (Miyazawa et al., 2003), which suggests a tight hydrophobic girdle around the pore at positions $9^{\prime}$ and $13^{\prime}$, and on the fact that at these positions residues along the entire family are highly conserved, we can propose that the interactions of side chains at $13^{\prime}$ and to a lesser extent at $9^{\prime}$ are key ones in creating an energetic barrier to ion permeation. This conclusion is based on the observation that the magnitude of the phenotypes observed was more overt in the case of the $13^{\prime} \mathrm{T}$ mutants and on the prediction that perturbation of the hydrophobic contacts by the introduction of a polar residue should increase the relative stability of the open pore (Miyazawa et al., 2003). However, further mutations to residues other than threonine would be needed in order to prove this notion.

A major effect of the threonine substitution at $13^{\prime}$, and to a lesser extent at $9^{\prime}$, was to create constitutive opened receptors, to enhance ACh sensitivity, and at the single-channel level to increase the apparent mean open time and consequently to stabilize the open state of the mutant receptors, with no major changes in channel conductance. This is consistent with the hypothesis that the conserved centrally located TM2 residues are important for ACh receptor gating (Labarca et al., 1995; Miyazawa et al., 2003), and that the mutations weaken the contacts that hold the channel in the closed state. 
In the case of wild-type $\alpha 9 \alpha 10 \mathrm{nAChRs}$, responses to $\mathrm{ACh}$ are tightly dependent upon the presence of external $\mathrm{Ca}^{2+}$ and responses at nominally zero $\mathrm{Ca}^{2+}$ are $5 \%$ of the maximal response obtained at $0.5 \mathrm{~mm}$ (Weisstaub et al., 2002). It has been suggested that $\mathrm{Ca}^{2+}$ probably interacts at an extracellular binding site to allosterically modulate coupling between $\mathrm{ACh}$ binding and gating (Galzi et al., 1996a; Weisstaub et al., 2002). One could expect that a mutation that increases ACh receptor gating should eventually result in mutant receptors that are less dependent upon the presence of extracellular divalent cations to favor transitions to the open state. This is consistent with the experimental data obtained for mutations at the $9^{\prime}$ and $13^{\prime}$ TM2 positions shown in Figure 2.

A mutation that increases the ability of a receptor to change its conformation, that is an increase in gating, should enhance the efficacy of partial agonists (Colquhoun, 1998). This is consistent with the observation that the partial agonist choline became a full agonist of mutant receptors. On the other hand, weak partial agonists may actually behave as antagonists of wild-type receptors, since their ability for driving the receptor to the open state once bound is very low; they lead to very few channel openings and do not give rise to measurable macroscopic currents (Rayes et al., 2004). Increased channel gating, introduced by the mutations, would lead to measurable macroscopic currents. This could account for the observation that antagonists of wild-type receptors became agonists of mutant receptors.

Although one might expect a mutation in the pore of the channel to affect its gating properties but not its ligandbinding site, there is no reason that this should be necessarily true in an allosteric protein like an ion channel (Colquhoun, 1998). Propagated conformational changes to the extracellular N-terminal domain of the protein could eventually subserve some of the observed changes. However, the fact that at the single-channel level mutant receptors exhibited a drastic increase in the apparent mean open time, together with the observation that the $\mathrm{ACh} \mathrm{EC}_{50}$ values for mutant receptors were inversely correlated to the degree of spontaneous openings of the channels, argues in favor of a direct effect on channel gating as the main underlying mechanism.

\section{Single-channel recordings in $\alpha 9 \alpha 10$ wild-type and mutant receptors}

The single-channel recordings are the first ones to be reported for the $\alpha 9 \alpha 10$ receptors. In spite of the fact that the number of patches in which we observed channels was extremely low, these channels were easily distinguished from the oocyte's endogenous channel activity due to their higher amplitude, which was enhanced by the use of solutions free of magnesium and low calcium to avoid channel block of $\alpha 9 \alpha 10$ receptors (Weisstaub et al., 2002). One possible explanation for the low rate of success in finding $\alpha 9 \alpha 10$ channels is that the density of receptors is very low in oocytes. In this regard, the average peak current obtained for wild-type $\alpha 9 \alpha 10$ nAChRs, $600 \mathrm{nA}$, is about ten-fold lower than that observed for the muscle $\mathrm{nAChR}, 9 \mu \mathrm{A}$ (Labarca et al., 1995), where successful single-channel recordings can be performed. A higher density of channels, with a very low probability of opening, could also explain the low rate of successful singlechannel recordings.

\section{Comparison to other Cys-loop receptors}

Similar mutagenesis approaches have been undertaken for other receptors of the 'Cys-loop' family (Revah et al., 1991; Filatov \& White, 1995; Labarca et al., 1995). These experiments have implicated the middle of the TM2 in the gating of the nAChR. Although a priori the phenotypes obtained in mutated $\alpha 9 \alpha 10$ receptors might only appear as confirmatory of those already published, important differences when compared to those of other nAChRs were observed.

The present results differ from those reported for the neuronal $\alpha 7$ nAChRs, where the magnitude of the phenotypes assessed by the shift in $\mathrm{ACh} \mathrm{EC}_{50}$, and the activation by classical antagonists is more overt for the L9' $\mathrm{T}$ than the $\mathrm{V} 13^{\prime} \mathrm{T}$ (Galzi et al., 1996b). Moreover, in the case of $\alpha 7 \mathrm{nAChRs,} \mathrm{an}$ additional conductance appears in the $9^{\prime} \mathrm{T}$ and $13^{\prime} \mathrm{T}$ mutants (Revah et al., 1991; Galzi et al., 1992). The fact that this was not observed in $\alpha 9 \alpha 10$ indicates that, different from that proposed for the $\alpha 7$ receptor (Bertrand et al., 1997), we do not need to invoke a conducting desensitized state to explain the observed results. However, we cannot disregard the fact that an additional conducting state might exist and could not be detected, either due to the low rate of success in finding channels or due to the fact that the new state has a low conductance that cannot be distinguished from that of the oocyte's endogenous stretch-activated channels. It is also possible that although amplitude histograms show a singlechannel population, different populations may not be distinguishable due to closely spaced conductances and unequal relative areas. The latter may result in broad amplitude histograms, as shown in Figure 6.

Hydrophilic substitutions of the L9' of muscle nAChR are nearly independent, equivalent and multiplicative in their effects on the ACh $\mathrm{EC}_{50}$ value (Filatov \& White, 1995; Labarca et al., 1995). On the contrary, the $\mathrm{EC}_{50}$ values obtained for single and double mutants of the $\alpha 9 \alpha 10 \mathrm{nAChRs}$ at $9^{\prime}$ and $13^{\prime}$ indicate that at these positions both types of subunits contribute in an asymmetric and nonadditive manner. This can be inferred from the fact that receptors containing only the $\alpha 9$ or the $\alpha 10$ mutant subunits showed the same decrease in the $\mathrm{EC}_{50}$ values, despite the fact that they cannot be in the same proportion in the pentameric assembly of a $\mathrm{nAChR}$, and that a sole population of receptors is observed in oocytes with a $(\alpha 9)_{2}(\alpha 10)_{3}$ stoichiometry (Plazas \& Elgoyhen, unpublished observations). Consequently, the $\mathrm{EC}_{50}$ values of $\alpha 9 \alpha 10$ receptors containing all mutant subunits $\left(\alpha 9^{*} \alpha 10^{*}\right.$, Table 1) are different from the ones calculated by multiplying the shifts in $\mathrm{EC}_{50}$ for receptors containing only $\alpha 9$ or $\alpha 10$ mutant subunits. Whether this reveals differences in the dynamics of the subunits during gating or results from an asymmetric orientation of the five subunits in the pore of the pentameric complex still has to be determined. However, following the atomic model of the pore, the five subunits of the receptor come into a close proximity at positions $9^{\prime}$ and $13^{\prime}$ and interaction of side chains from different subunits takes place (Miyazawa et al., 2003). Thus, it is not surprising that a conformational change in one subunit can influence other subunits.

Different results were obtained at the more extracellular $17^{\prime}$ position, where mutations to threonine in either $\alpha 9$ or $\alpha 10$ lead to 2.6- and 5.1-fold decreases in the $\mathrm{EC}_{50}$ values, respectively. The expected shift for the double-mutant receptor if both types 
of subunits contribute independently to ACh sensitivity would be 13.3-fold. Interestingly, this agrees with the experimentally calculated decrease in the $\mathrm{EC}_{50}$ value (13.4-fold, Table 1). Therefore, it can be postulated that at this position both types of subunits contribute independently and symmetrically to ACh sensitivity, a result which could be explained if, as suggested in the atomic model (Miyazawa et al., 2003), the 17' residues are not located at the girdle of the pore. Again, this differs from that described for the neighboring $16^{\prime}$ residue of the muscle nAChR, where the contributions of the different subunits to gating are nonsymmetrical (Labarca et al., 1995).

\section{Conclusion}

The present experimental data analyze for the first time the participation of different TM2 residues in gating of the $\alpha 9 \alpha 10$ nAChR. We show evidence indicating that the centrally located amino acids at $9^{\prime}$ and $13^{\prime}$ are involved in activation of the $\alpha 9 \alpha 10 \mathrm{nAChR}$. In general, our results show that although the roles of the TM2 residues are mostly conserved in the distant $\alpha 9 \alpha 10$ member of the nAChR family, their mechanistic contributions to channel gating show significant differences. These differences might be originated from slight differential intramolecular rearrangements during gating for the different receptors and might lead each nAChR to be in tune with their physiological roles. Thus, results obtained from one type of receptor cannot be necessarily directly extrapolated to other receptors of the same family.

We want to thank Dr Claudio Grosman for his critical discussion in the interpretation of the experimental results. This work was supported by an International Research Scholar Grant from the Howard Hughes Medical Institute, a John Simon Guggenheim Memorial Foundation Fellowship, The National Organization for Hearing Research (U.S.A.), Laboratorios Temis-Lostaló, Argentina and a Research Grant from ANPCyT and UBA (Argentina) to ABE, and grants from ANPCyT, CONICET and UNS (Argentina) to CB.

\section{References}

AKABAS, M.H., KAUfMANN, C., ARCHDEACON, P. \& KARLin, A. (1994). Identification of acetylcholine receptor channel-lining residues in the entire M2 segment of the alpha subunit. Neuron, 13, 919-927.

ARELLANO, R.O., WOODWARD, R.M. \& MILEDI, R. (1995). A monovalent cationic conductance that is blocked by extracellular divalent cations in Xenopus oocytes. J. Physiol. (London), 484, 593-604.

BERTRAND, D., DEVILLERS-THIERY, A., REVAH, F., GALZI, J.L., HUSSY, N., MULLE, C., BERTRAND, S., BALLIVET, M. \& CHANGEUX, J.P. (1992). Unconventional pharmacology of a neuronal receptor mutated in the channel domain. Proc. Natl. Acad. Sci. U.S.A., 89, 1261-1265.

BERTRAND, D., GALZI, J.L., DEVILLERS-THIERY, A., BERTRAND, S. \& CHANGEUX, J.P. (1993). Stratification of the channel domain in neurotransmitter receptors. Curr. Opin. Cell Biol., 5, 688-693.

BERTRAND, S., DEVILlERS-THIERY, A., PALMA, E., BUISSON, B., EDELSTEIN, S.J., CORRINGER, P.J., CHANGEUX, J.P. \& BERTRAND, D. (1997). Paradoxical allosteric effects of competitive inhibitors on neuronal alpha7 nicotinic receptor mutants. NeuroReport, 8, 3591-3596.

BOUZAT, C., BREN, N. \& SINE, S. (1994). Structural basis of the different gating kinetics of fetal and adult acetylcholine receptors. Neuron, 13, 1395-1402.

BOUZAT, C., GUMILAR, F., DEL CARMEN ESANDI, M. \& SINE, S.M. (2002). Subunit-selective contribution to channel gating of the M4 domain of the nicotinic receptor. Biophys. J., 82, 1920-1929.

CHANG, Y. \& WEISS, D.S. (1998). Substitutions of the highly conserved M2 leucine create spontaneously opening rhol gamma-aminobutyric acid receptors. Mol. Pharmacol., 53, 511-523.

CHANG, Y. \& WEISS, D.S. (1999). Allosteric activation mechanism of the alpha1beta2gamma2 gamma-aminobutyric acid type A receptor revealed by mutation of the conserved M2 leucine. Biophys. J., 77, 2542-2551.

COLQUHOUN, D. (1998). Binding, gating, affinity and efficacy: the interpretation of structure-activity relationships for agonists and of the effects of mutating receptors. Br. J. Pharmacol., 125, 924-947.

CORRINGER, P.J., BERTRAND, S., GALZI, J.L., DEVILLERS-THIERY, A., CHANGEUX, J.P., BERTRAND, D. \& HUSSY, N. (1999). Mutational analysis of the charge selectivity filter of the alpha7 nicotinic acetylcholine receptor. Neuron, 22, 831-843.

CYMES, G.D., GROSMAN, C. \& AUERBACH, A. (2002). Structure of the transition state of gating in the acetylcholine receptor channel pore: a phi-value analysis. Biochemistry, 41, 5548-5555.
EBIHARA, L. (1996). Xenopus connexin38 forms hemi-gap-junctional channels in the nonjunctional plasma membrane of Xenopus oocytes. Biophys. J., 71, 742-748.

ELGOYHEN, A.B., JOHNSON, D.S., BOULTER, J., VETTER, D.E. \& HEINEMANN, S. (1994). Alpha9: an acetylcholine receptor with novel pharmacological properties expressed in rat cochlear hair cells. Cell, 79, 705-715.

ELGOYHEN, A.B., VETTER, D., KATZ, E., ROTHLIN, C., HEINEMANN, S. \& BOUlTER, J. (2001). Alpha 10: a determinant of nicotinic cholinergic receptor function in mammalian vestibular and cochlear mechanosensory hair cells. Proc. Natl. Acad. Sci. U.S.A., 98, 3501-3506.

ENGLAND, P.M., ZHANG, Y., DOUGHERTY, D.A. \& LESTER, H.A. (1999). Backbone mutations in transmembrane domains of a ligandgated ion channel: implications for the mechanism of gating. Cell, 96, 89-98.

FILATOV, G.N. \& WHITE, M.M. (1995). The role of conserved leucines in the M2 domain of the acetylcholine receptor in channel gating. Mol. Pharmacol., 48, 379-384.

GALZI, J.L., BERTRAND, S., CORRINGER, P.J., CHANGEUX, J.P. \& BERTRAND, D. (1996a). Identification of calcium binding sites that regulate potentiation of a neuronal nicotinic acetylcholine receptor. EMBOJ., 15, 5824-5832.

GALZI, J.L., DEVILLERS-THIERY, A., HUSSY, N., BERTRAND, S., CHANGEUX, J.P. \& BERTRAND, D. (1992). Mutations in the channel domain of a neuronal nicotinic receptor convert ion selectivity from cationic to anionic. Nature, 359, 500-505.

GALZI, J.L., EDELSTEIN, S.J. \& CHANGEUX, J. (1996b). The multiple phenotypes of allosteric receptor mutants. Proc. Natl. Acad. Sci. U.S.A., 93, 1853-1858.

GRIGORIEV, N.G., SPAFFORD, J.D. \& SPENCER, A.N. (1999). The effects of level of expression of a jellyfish Shaker potassium channel: a positive potassium feedback mechanism. J. Physiol. (London), 517 (Part 1), 25-33.

HAMILL, O.P. \& SAKMANN, B. (1981). Multiple conductance states of single acetylcholine receptor channels in embryonic muscle cells. Nature, 294, 462-464.

KARLIN, A. \& AKABAS, M. (1995). Toward a structural basis for the function of nicotinic acetylcholine receptors and their cousins. Neuron, 15, 1231-1244.

KATZ, E., VERBITSKY, M., ROTHLIN, C., VETTER, D., HEINEMANN, S. \& ELGOYHEN, A. (2000). High calcium permeability and calcium block of the $\alpha 9$ nicotinic acetylcholine receptor. Hearing Res., 141, $117-128$.

LABARCA, C., NOWAK, M.W., ZHANG, H., TANG, L., DESHPANDE, P. \& LESTER, H.A. (1995). Channel gating governed symmetrically by conserved leucine residues in the M2 domain of nicotinic receptors. Nature, 376, 514-516. 
LENOVERE, N. \& CHANGEUX, J. (1995). Molecular evolution of the nicotinic acetylcholine receptor: an example of multigene family in excitable cells. J. Molec. Evol., 40, 155-172.

LENOVERE, N., CORRINGER, P.J. \& CHANGEUX, J.P. (2002). The diversity of subunit composition in nAChRs: evolutionary origins, physiologic and pharmacologic consequences. J. Neurobiol., 53, 447-456.

MIYAZAWA, A., FUJIYOSHI, Y. \& UNWIN, N. (2003). Structure and gating mechanism of the acetylcholine receptor pore. Nature, $\mathbf{4 2 4}$, 949-955.

PANICKER, S., CRUZ, H., ARRABIT, C. \& SLESINGER, P.A. (2002). Evidence for a centrally located gate in the pore of a serotoningated ion channel. J. Neurosci., 22, 1629-1639.

PAPKE, R.L., BENCHERIF, M. \& LIPPIELLO, P. (1996). An evaluation of neuronal nicotinic acetylcholine receptor activation by quaternary nitrogen compounds indicates that choline is selective for the a7 subtype. Neurosci. Letters, 213, 201-204.

RAYES, D., DEROSA, M., BARTOS, M. \& BOUZAT, C. (2004). Molecular basis of the differential sensitivity of nematode and mammalian muscle to the anthelmintic agent levamisole. J. Biol. Chem., 279, 36372-36381.
REVAH, F., BERTRAND, D., GALZI, J., DEVILlERS-THIÉRY, A., MULLE, C., HUSSY, N., BERTRAND, S., BALLIVET, M. \& CHANGEUX, J. (1991). Mutations in the channel domain alter desensitization of a neuronal nicotinic receptor. Nature, $\mathbf{3 5 3}$ 846-848.

TAGLIETTI, V. \& TOSELLI, M. (1988). A study of stretch-activated channels in the membrane of frog oocytes: interactions with $\mathrm{Ca}^{2+}$ ions. J. Physiol. (London), 407, 311-328.

VERBITSKY, M., ROTHLIN, C., KATZ, E. \& ELGOYHEN, A.B. (2000). Mixed nicotinic-muscarinic properties of the a9 nicotinic cholinergic receptor. Neuropharmacology, 39, 2515-2524.

WEISSTAUB, N., VETTER, D., ELGOYHEN, A. \& KATZ, E. (2002). The alpha9/alpha10 nicotinic acetylcholine receptor is permeable to and is modulated by divalent cations. Hearing Res., 167, 122-135.

WILSON, G.G. \& KARLIN, A. (1998). The location of the gate in the acetylcholine receptor channel. Neuron, 20, 1269-1281.

(Received January 4, 2005

Revised March 8, 2005

Accepted March 8, 2005

Published online 16 May 2005) 